\title{
EFEK PROTEIN SEMPURNA DAN TIDAK SEMPURNA TERHADAP BERAT BADAN DAN ALBUMIN TIKUS
}

\section{EFFECT OF PROTEIN COMPLETE AND UNCOMPLETE TO WEIGHT GAIN AND ALBUMIN IN WISTAR}

\author{
Hermawati $^{1}$, Abdul Salam ${ }^{1}$, Sabaria Manti Battung ${ }^{1}$ \\ (No Hp dan Email: 085242789990 dan hrmwtrm@gmail.com) \\ ${ }^{1}$ Program Studi Ilmu Gizi, Universitas Hasanuddin, Makassar
}

\begin{abstract}
ABSTRAK
Pendahuluan: Protein merupakan pemicu kejadian obesitas dan perubahan kadar albumin dalam tubuh. Obesitas salah satu tantangan kesehatan masyarakat paling serius di abad ke-21. Tujuan: Penelitian ini bertujuan untuk mengetahui efek pemberian diet tinggi protein sempurna dan tidak sempurna terhadap perubahan berat badan dan kadar albumin tikus. Bahan dan Metode: Sampel menggunakan 15 ekor tikus wistas yang dibagi secara acak dalam 3 kelompok, masing-masing terdiri dari 5 ekor dengan berat 150-200 g serta dalam kondisi sehat. Pakan standar AD 2 diberikan pada kelompok kontrol, pakan intervensi susu yang diberikan pada kelompok protein sempurna dan pakan intervensi kedelai pada kelompok protein tidak sempurna. Penelitian dilakukan selama 6 minggu, 2 minggu adaptasi dan 4 minggu pemberian intervensi. Metode penelitian menggunakan true experiment dengan Randomized pretest-posttest control grup desigen. Data yang dikumpulkan berupa penimbangan berat badan dan pengukuran kadar albumin tikus yang dilakukan sebanyak 2 kali sebelum intervensi hari ke-0 dan setelah intervensi hari ke-28. Analisis data menggunakan uji statistik One Way ANOVA dilanjutkan Post Hoc Tukey dan uji Paired Sample Test bermakna bila $\mathrm{p} \leq 0,05$. Hasil: Hasil pengukuran berat badan yang diperoleh sebelum intervensi tidak signifikan dengan nilai $\mathrm{p}=0,790$ dan pengukuran setelah intervensi diperoleh hasil yang signifikan dengan nilai $p=0,014$, begitu pula dengan pemeriksaan kadar albumin tidak signifikan sebelum intervensi dengan nilai $\mathrm{p}=0,251$ dan signifikan di pemeriksaan setelah intervensi dengan nilai $p=0,003$. Kesimpulan: Dapat disimpulkan bahwa terdapat perubahan setelah intervensi untuk berat badan dan kadar albumin.
\end{abstract}

Kata Kunci: Protein, Berat Badan, Kadar Albumin.

\section{ABSTRACT}

Introduction: Protein is the trigger for the occurrence of obesity and changes in albumin levels in weight gain. Obesity is one of the most serious public health challenges in the 21st century. Objektive: This study aimed to determine the effects of high-protein complete and uncomplete diet to weight gain and albumin levels in wistar rats. Methods: The samples used 15 wistas rats which were divided randomly into 3 groups, each consisting of 5 tails weighing 150-200 $\mathrm{g}$ and in healthy condition. Standard AD 2 feed was given to the control group, intervention feed given to complete protein and soybean intervention feed protein group was uncomplete. The study was conducted for 6 weeks, 2 weeks of adaptation and 4 weeks of intervention. The research method used a true experiment with a randomized control group pretest-posttest desigen. The data collected consisted of weighing the body and measuring the rat albumin level which was carried out 2 times before the intervention day 0 and after the intervention of the 28th day. Data analysis used One Way ANOVA statistical test followed by Post Hoc Tukey and Paired Sample Test was accepted if $p<0.05$. Results: The results of measurements of weight gain obtained before the intervention were not significant with $p=0.790$ and measurements after intervention obtained significant results with a value of $p=0.014$, as well as examination of insignificant albumin levels before intervention with $p=0.251$ and significant on examination after the intervention with a value of $p=0.003$. Conclusion: It It can be concluded as an intervention after weight gain and albumin levels.

Keywords: protein, weight gain, albumin levels 


\section{PENDAHULUAN}

Obesitas merupakan salah satu tantangan kesehatan masyarakat paling serius di abad ke- 21 . Masalah obesitas terus meningkat dan mempengaruhi banyak negara-negara di dunia baik negara maju dan negara berkembang, terutama di perkotaan ${ }^{1}$. Dalam sepuluh tahun terakhir obesitas telah menjadi masalah global. Prevalensi obesitas di dunia meningkat lebih dari sepuluh kali lipat. Menurut data World Health Organization (WHO) tahun 2018, dalam empat dekade terakhir jumlah anak-anak dan remaja berusia 5-19 tahun hanya terdapat 11 juta yang mengalami obesitas pada tahun 1975, dan pada tahun 2016 meningkat menjadi 124 juta yang mengalami obesitas dan 213 mengalami kelebihan berat badan $^{2}$.

Kegemukan dan obesitas merupakan resiko terjadinya kematian. Setidaknya ada 2,8 juta orang dewasa meninggal setiap tahun sebagai akibat dari kelebihan berat badan atau obesitas ${ }^{3}$. Terdapatnya hubungan yang bermakna antara asupan protein dengan kegemukan disebabkan karena kelebihan protein akan diubah menjadi lemak dan akan disimpan di dalam tubuh. Makanan yang tinggi protein biasanya tinggi lemak. Dengan demikian, konsumsi protein secara berlebihan dapat menyebabkan kegemukan ${ }^{4}$. Pada penelitian yang dilakukan oleh ${ }^{5}$ pemberian diet tinggi protein ( $40 \%$ protein) dan diet protein sedang (20\%) menurunkan berat badan, memperbaiki komposisi tubuh, dan mengatur respons glikemik. Diet tinggi protein selama 12 minggu yang dilakukan pada pada tikus gemuk mengurangi kenaikan berat badan secara signifikan.

Albumin merupakan transpor protein tubuh yang mengindikasikan status protein sebagai respon dari konsumsi makanan terutama makanan sumber protein ${ }^{6}$. Pada penelitian yang dilakukan oleh $^{5}$ terdapat efek peningkatan yang signifikan terhadap intervensi tikus tanpa lemak dalam pemberian diet tinggi protein sebanyak $40 \%$, dengan konsumsi makanan yang berprotein pada konsetrasi asam amino.

Dengan melihat permasalahan di atas, diketahui bahwa salah satu faktor penyebab terjadinya obesitas adalah karena asupan protein yang berlebihan. Namun, karena adanya beberapa penelitan yang menemukan bahwa asupan protein tidak begitu memiliki hubungan terhadap kejadian obesitas, tapi tidak dijelaskan sumper protein apa yang dapat mencegah kejadian obesitas, maka peneliti ingin melihat bagaimana efek pemberian asupan protein yang berlebihan dalam hal ini pemberian diet tingg protein sempurna dan diet tinggi protein tidak sempurna terhadap perubahan berat badan atau obesitas dan kadar albumin.

\section{BAHAN DAN METODE}

\section{Jenis, Lokasi, dan Waktu Penelitian}

Jenis penelitian eksperimental dengan pendekatan Randomized pretest posttest control design. Penelitian ini dilakukan di Laboratorium Biofarmasi, Fakultas Farmasi, Universitas Hasanuddin. Waktu pelaksanaan pada bulan 18 April - 31 Mei 2019. Penelitian ini dilakukan selama 6 minggu.

Populasi dalam penelitian ini adalah tikus Wistar jantan. Sampel dalam penenlitian ini adalah 
tikus wistar (Rattus norvegicus) jenis kelamin jantan yang berasal dari wiraswasta hewan yang bersertifikat dan memberikan jaminan kesehatan tikus dengan berat badan 150-200 g. Sampel diambil secara random sampling. Alat yang digunakan pada penelitian ini yaitu kandang hewan coba, kanula, spuit, handscoon, vacutainer, microtube, timbangan pakan, spektrofotometer, wadah makanan, disprenser khusus, alat kebersihan, alat tulis. Bahan yang digunakan pada penelitian ini yaitu tikus Wistar jantan sesuai inklusi, pakan standar AD 2 (pakan tikus), tepung susu skim, tepung kedelai, albumin liquicolor, akuades dan sekam. Penelitian ini terdiri dari 15 ekor tikus yang dibagi secara acak dalam 3 kelompok, masing-masing terdiri dari 5 ekor dan masa adaptasi selama 2 minggu. Pakan standar AD 2 diberikan secara ad libitum di pagi hari pada kelompok kontrol sebanyak 20g/200gBBtikus/hari, pakan intervensi susu yang diberikan lewat kanula pagi dan siang hari pada kelompok protein sempurna sebanyak 10,11g/200gBBtikus/hari dalam bentuk cair kemudian diberikan pakan standar setelah intervensi sebanyak 9,89g/200gBBtikus/hari dan pakan intervensi kedelai yang diberikan secara ad libitum di pagi hari pada kelompok protein tidak sempurna sebanyak $10 \mathrm{~g} / 200 \mathrm{gBBtikus} /$ hari dalam bentuk pellet kemudian diberikan pakan standar setelah intervensi sebanyak $10 \mathrm{~g} / 200 \mathrm{gBB}$ tikus/hari.

Pengukuran berat badan dan pemeriksaan kadar albumin dilakukan sebanyak 2 kali. Tahap pertama dilakukan sesudah tikus diadaptasi atau sebelum intervensi yaitu pada hari ke-0, hasil ini dijadikan pretest Tahap kedua dilakukan setelah intervensi yaitu pada hari ke-28. Prosedur pengukuran berat badan dan pengambilan darah di hari ke-28, hasil ini dijadikan hasil posttest. Pengukuran kadar albumin darah diambil sebanyak $1 \mathrm{~mL}$ yang diambil dari ekor tikus putih. Pengambilan darah dilakukan pada pagi hari. Pengambilan data dilakukan dengan cara mengukur kadar albumin tikus putih menggunakan metode Bromocresol Green dengan alat spektrofotometer. Sampel darah yang telah diambil dimasukkan dalam tabung reaksi, kemudian plasma dipisahkan dari darah dengan cara sentrifuge selama 10 menit dengan kecepatan $3000 \mathrm{rpm}$. Kemudian diambil $10 \mu \mathrm{L}$ plasma dan ditambahkan $1000 \mu \mathrm{L}$ reagen albumin liquicolor, selanjutnya tabung sampel diinkubasi selama 10 menit pada suhu $20-25^{\circ} \mathrm{C}$. Hasil inkubasi dimasukkan ke dalam spektrofotometer dengan panjang gelombang $546 \mathrm{~mm}$, kemudian hasil pengukuran dibaca dalam satuan $\mathrm{g} / \mathrm{dL}$.

Data nilai berat badan diperoleh dari hasil penimbangan dan data nilai kadar albumin tikus yang diperoleh dari hasil pengambilan sampel darah dengan metode bromocresol green. Analisis data secara komputerisasi dengan menggunakan program SPSS 18.00. Kemudian data diolah menggunakan uji One Way ANOVA. Sebelum uji One Way ANOVA digunakan terlebih dahulu dilakukan uji Normalitas dan uji Homogenitas untuk melihat signifikan data bermakna bila $\mathrm{p} \geq 0,05$. Uji lanjutnya menggunakan uji Post Hoc Tukey untuk melihat perbedaan dari antar kelompok, bermakna bila $\mathrm{P} \leq 0,05$. Selain dibandingkan antar kelompok, juga dilakukan uji dalam setiap kelompok dengan menggunakan uji Paired Sampel Test, bermakna bila $\mathrm{p} \leq 0,05$. 


\section{HASIL}

Berdasarkan hasil berat badan pada tabel 1 Setelah memenuhi syarat inklusi dan melalui masa adaptasi selama 2 minggu, selanjutnya dilakukan penimbangan berat badan sebelum pemberian intervensi (pretest) hari ke 0 . Berdasarkan hasil yang diperoleh pengukuran berat badan tikus hari ke 0 dengan nilai $\mathrm{p}>0,05$. Hal ini berarti tidak terdapat perbedaan rata-rata berat badan antara kelompok kontrol, perlakuan 1 (pemberian susu), dan kelompok perlakuan 2 (pemberian kedelai) sebelum intervensi.

Tabel 1. Berat Badan Sebelum dan Setelah Intervensi

\begin{tabular}{ccccc}
\hline $\begin{array}{c}\text { Rata-Rata } \\
\text { Berat Badan }\end{array}$ & Kontrol & Susu & Kedelai & $\boldsymbol{P}^{* *}$ \\
& $($ Mean \pm SD) & (Mean \pm SD) & $($ Mean \pm SD) & \\
\hline Hari ke 0 & $166.80 \pm 6.49$ & $171.80 \pm 6.15$ & $167.60 \pm 3.14$ & 0.790 \\
Hari ke 28 & $210.36 \pm 13.63^{\mathrm{a}}$ & $175.60 \pm 7.54$ & $165.60 \pm 4.86^{\mathrm{b}}$ & $0.014^{* *}$ \\
$\boldsymbol{P}^{*}$ & $0.020^{*}$ & 0.791 & 0.495 & \\
\hline
\end{tabular}

Sumber : Data Primer, 2019.

Keterangan : $\quad p^{*}=$ Uji Paired Test terdapat perbedaan rata rata berat badan signifikan antar kelompok yang sama $(\mathrm{p}<0,05)$

$p^{* *}=$ Uji Anova terdapat perbedaan rata rata berat badan signifikan antar kelompok $(\mathrm{p}<0,05)$

$\mathrm{a}, \mathrm{b}=$ Yang memiliki huruf sama berarti signifkan berbeda berdasarkan hasil Post Hoc Tukey $(\mathrm{p}<0,05)$

Setelah masa adaptasi kemudian tikus diintervensi selama 4 minggu dan dilakukan penimbangan berat badan akhir setelah intervensi (posttest) pada hari ke 28. Berdasarkan hasil yang diperoleh pengukuran berat badan tikus hari ke 28 dengan nilai $\mathrm{p}<0,05$. Hal ini berarti terdapat perbedaan rata-rata berat badan antara kelompok kontrol, perlakuan 1 (pemberian susu), dan kelompok perlakuan 2 (pemberian kedelai) setelah intervensi. Selanjutnya dilakukan uji beda lanjut Post Hoc Tukey untuk melihat perbedaan yang lebih jelas.

Berdasarkan hasil uji Post Hoc Tukey pada tabel 1 diperoleh hasil perubahan berat badan yang signifikan setelah intervensi pada hari ke 28 antar kelompok kontrol dengan perlakuan 2 (kedelai). Untuk mengetahui apakah terdapat perbedaan perubahan berat badan signifikan dalam kelompok kontrol, kelompok perlakuan 1 (susu), dan kelompok perlakuan 2 (kedelai) maka dilakukan uji Paired Sampel Test.

Uji Paired Sampel Test pada tabel 1 untuk mengetahui adanya perubahan berat badan yang signifikan dalam setiap kelompok. Berdasarkan hasil yang diperoleh bahwa kelompok kontrol dengan niali $\mathrm{p}<0,05$ berarti terjadi perubahan yang signifikan. Namun tidak dengan kelompok perlakuan 1 
(susu) dan kelompok perlakuan 2 (kedelai).

Berdasarkan hasil uji yang dilakukan dapat disimpulkan bahwa perubahan berat badan yang terjadi dalam kelompok kontrol mengalami perubahan berat badan yang signifikan dalam hal ini kenaikan berat badan tetapi dalam kelompok perlakuan 1 (susu) dan kelompok perlakuan 2 (kedelai) tidak signifikan mengalami perubahan atau berat badannya cenderung tetap.

Tabel 2. Kadar Albumin Sebelum dan Setelah Intervensi

\begin{tabular}{ccccc}
\hline $\begin{array}{c}\text { Rata-Rata } \\
\text { Kadar } \\
\text { Albumin }\end{array}$ & Kontrol & Susu & Kedelai & $\boldsymbol{P}^{* *}$ \\
& $($ Mean \pm SD) & (Mean \pm SD) & (Mean \pm SD) & \\
\hline Hari ke 0 & $4.02 \pm 0.14$ & $3.71 \pm 0.22$ & $4.11 \pm 0.12$ & 0.251 \\
Hari ke 28 & $4.06 \pm 0.35$ & $4.81 \pm 0.12^{\mathrm{a}}$ & $3.13 \pm 0.24^{\mathrm{b}}$ & $0.003^{* *}$ \\
$\boldsymbol{P}^{*}$ & 0.937 & $0.004^{*}$ & $0.005^{*}$ & \\
\hline
\end{tabular}

Sumber : Data Primer, 2019.

Keterangan : $\quad *=$ Uji Paired Test terdapat perbedaan rata rata kadar albumin signifikan antar kelompok yang sama $(\mathrm{p}<0,05)$

** = Uji Anova terdapat perbedaan rata rata berat badan signifikan antar kelompok $(\mathrm{p}<0,05)$

a,b $\quad$ Yang memiliki huruf sama berarti signifkan berbeda berdasarkan hasil Post Hoc Tukey $(\mathrm{p}<0,05)$

Berdasarkan hasil berat badan pada tabel 2 merupakan hasil pemeriksaan kadar albumin sebelum pemberian intervensi (pretest) hari ke 0 . Berdasarkan hasil yang diperoleh pemeriksaan kadar albumin tikus hari ke 0 dengan nilai $p>0,05$. Hal ini berarti tidak terdapat perbedaan rata-rata kadar albumin antara kelompok kontrol, perlakuan 1 (susu), dan kelompok perlakuan 2 (kedelai) sebelum intervensi.

Tikus yang telah diintervensi selama 4 minggu dan dilakukan pemeriksaan kadar albumin (posttest) pada hari ke 28. Berdasarkan hasil yang diperoleh pemeriksaan kadar albumin tikus hari ke 28 dengan nilai $\mathrm{p}<0,05$. Hal ini berarti terdapat perbedaan rata-rata kadar albumin antara kelompok kontrol, perlakuan 1 (susu), dan kelompok perlakuan 2 (kedelai) setelah intervensi. Selanjutnya dilakukan uji beda lanjut Post Hoc Tukey untuk melihat perbedaan yang lebih jelas.

Berdasarkan hasil uji Post Hoc Tukey pada tabel 2 diperoleh hasil perubahan kadar albumin yang signifikan setelah intervensi pada hari ke 28 antar kelompok perlakuan 1 (susu) dengan perlakuan 2 (kedelai).

Untuk mengetahui apakah terdapat perbedaan perubahan kadar albumin signifikan dalam kelompok kontrol, kelompok perlakuan 1 (susu), dan kelompok perlakuan 2 (kedelai) maka dilakukan uji Paired Sampel Test. 
Uji Paired Sampel Test pada tabel 2 untuk mengetahui adanya perubahan berat badan yang signifikan dalam setiap kelompok. Berdasarkan hasil yang diperoleh bahwa kelompok perlakuan 1 (susu) dan kelompok perlakuan 2 (kedelai) dengan niali $\mathrm{p}<0,05$ berarti terjadi perubahan yang signifikan. Namun tidak dengan kelompok kontrol.

Berdasarkan hasil uji yang dilakukan dapat disimpulkan bahwa perubahan kadar albumin yang terjadi dalam kelompok perlakuan 1 (susu) dan kelompok perlakuan 2 (kedelai) mengalami perubahan kadar albumin yang signifikan tetapi dalam kelompok kontrol tidak signifikan mengalami perubahan atau kadar albuminnya cenderung tetap.

\section{PEMBAHASAN}

Berdasarkan hasil penelitian pada tabel 1 terjadi perubahan berat badan pada setiap kelompok. Pada kelompok kontrol mengalami peningkatan berat badan yang signifikan. Berdasarkan teori tikus yang sehat dan dipelihara dengan baik dan berada dalam kondisi seimbang antara konsumsi dan asupan makan, maka berat badan tikus akan naik mengikuti pola pertumbuhan dan perkembangannya sekitar 5 gram per hari ${ }^{7}$.

Kelompok perlakuan 1 (susu) mengalami peningkatan berat badan yang tidak signifika. Berdasarkan teori protein berhubungan dengan kegemukan dan jenis protein merupakan faktor dari perubahan berat badan ${ }^{4,8}$. Berdasarkan penelitian kandungan protein whey pada susu berhubungan dengan peningkatan massa otot, hormon pertumbuhan Insulin-like Growth Factor (IGF)-1 yang merangsang sintesis protein memberikan peningkatan nafsu makan dengan efek peningkatan berat badan pada subjek normal atau kurus 9 . Dapat disimpulkan peningkatan berat badan yang terjadi pada kelompok perlakuan 1 (susu) karena peningkatan massa otot dimana tikus yang diintervensi tergolong tikus yang sehat sehingga kandungan protein whey yang terdapat dalam susu memberikan peningkatan nafsu makan dengan efek peningkatan berat badan.

Sedangkan kelompok perlakuan 2 (kedelai) mengalami penurunan berat badan. Berdasarkan teori senyawa flavonoid dalam kedelai yang lebih dikenal sebagai isoflavon kedelai merupakan senyawa non-nutritif. Kedelai salah satu sumber protein berkualitas dengan kandungan lemak jenuh yang rendah dan bebas kolesterol ${ }^{10}$. Berdasarkan penelitian kadar isoflavon yang terdapat dalam kedelai yang mengandung flavonoid, merupakan penghambatan kenaikan berat badan tikus karena kandungan isoflavon yang terdapat didalamnya ${ }^{7}$. Dapat disimpulkan perubahan yang diberikan dalam hal ini yaitu penurunan berat badan tikus, dimana penurunan yang terjadi selain kandungan flavonoid juga karena kandungan lemak tak jenuh dalam kedelai yang dapat menurunkan berat badan.

Berdasarkan hasil penelitian terjadi perubahan kadar albumin pada setiap kelompok. Pada kelompok kontrol mengalami peningkatan kadar albumin. Berdasarkan teori asupan energi yang cukup maka protein tidak akan dipecah menjadi energi sehingga protein benar-benar digunakan untuk pembetukan protein tubuh termasuk albumin ${ }^{11}$.Berdasarkan penelitian kenaikan kadar albumin pada kelompok kontrol dipengaruhi oleh status gizi yang baik ${ }^{12}$. Penelitian ini juga dikaitkan dengan 
penelitian berdasarkan jenis kelamin dimana kadar albumin laki-laki lebih tinggi dibandingkan perempuan karena laki-laki memiliki laju sintesis albumin yang lebih tinggi ${ }^{13}$. Dapat disimpulkan perubahan dalam hal ini merupakan peningkatan albumin namun, peningkatan yang diberikan juga kurang efektif diakibatkan kandungan protein dalam pakan standar yang digunakan juga sedikit.

Kelompok perlakuan 1 (susu) juga mengalami peningkatan kadar albumin yang signifikan. Berdasarkan teori dimana sintesis protein dalam hati terutama sintesis albumin sangat responsif terhadap influks (masukan) asam amino dari makanan. Jika asupan protein meningkat maka sintesis albumin juga akan meningkat. Albumin sebagai transpor protein tubuh yang mengindikasikan status protein merupakan respon dari konsumsi makanan terutama makanan sumber protei ${ }^{6}$. Berdasarkan penelitian terjadi peningkatan yang signifikan terhadap intervensi tikus tanpa lemak dalam pemberian diet tinggi protein sebanyak 40\%, dengan konsumsi makanan yang berprotein pada konsetrasi asam amino $^{5}$. Dapat disimpulkan perubahan yang terjadi dalam hal ini yaitu peningkatan kadar abumin, dikarena susu merupakan asam amino esensial. Sehingga asupan asam amino memberikan efek peningkatan terhadap kadar albumin, dan peningkatan yang diberikan juga masih dalam batas normal.

Susu merupakan protein tinggi yang mengandung asam amino yang lengkap baik jenis maupun jumalahnya. Susu tinggi protein mengandung dua komponen protein utama yaitu protein kasein dan protein whey. Kadar kasein pada protein susu mencapai $80 \%$ dari jumlah protein yang terdapat dalam susu sapi, sedangkan protein whey sebanyak $20 \%$. Kandungan protein whey pada susu yaitu $\alpha$ lactalbumin ( $\alpha$-LA, 20\%), $\beta$-lactoglobulin ( $\beta$ - Lg, 50\%), serum albumin (BSA, 10\%), immunoglobulins $(10 \%)$ dan peptones protease $(<10 \%)^{15}$.

Kelompok perlakuan 2 (kedelai) juga mengalami penurunan kadar albumin. Berdasarkan teori faktor penyebab penurunan kadar albumin karena kurangnya kandungan asam amino esensial yang terdapat dalam bahan makanan yang dikonsumsi ${ }^{6}$. Berdasarkan penelitian kadar albumin pada vegetarian lebih rendah dibandingkan dengan non-vegetarian, tapi dalam batas normal. Hal ini disebabkan diet vegetarian dominan memiliki kandungan asam amino yang lebih sedikit dan kemampuan untuk dicerna yang lebih rendah dibandingkan diet protein hewani. Salah satu penyebab kadar albumin menurun karena kurangnya sintesis albumin dalam tubuh ${ }^{16}$. Dapat disimpulkan perubahan dalam hal ini yaitu penurunan kadar albumin namun penurunan yang diberikan masih dalam batas normal, karena pakan kedelai yang diguna merupakan sumber protein dengan kualitas yang terbaik.

\section{KESIMPULAN DAN SARAN}

Terdapat perubahan berat badan kelompok kontrol, kelompok diet tinggi protein sempurna dan kelompok diet tinggi tinggi protein tidak sempurna sebelum dan setelah intervensi. Terdapat perubahan berat badan antara kelompok kontrol, kelompok diet tinggi protein sempurna dan kelompok diet tinggi tinggi protein tidak sempurna sebelum dan setelah intervensi. Terdapat perubahan berat badan setiap kelompok kontrol, kelompok diet tinggi protein sempurna dan kelompok diet tinggi tinggi protein tidak sempurna sebelum dan setelah intervensi. Terdapat perubahan kadar albumin kelompok kontrol, 
kelompok diet tinggi protein sempurna dan kelompok diet tinggi tinggi protein tidak sempurna sebelum dan setelah intervensi. Terdapat perubahan kadar albumin antar kelompok kontrol, kelompok diet tinggi protein sempurna dan kelompok diet tinggi tinggi protein tidak sempurna sebelum dan setelah intervensi. Terdapat perubahan kadar albumin setiap kelompok kontrol, kelompok diet tinggi protein sempurna dan kelompok diet tinggi tinggi protein tidak sempurna sebelum dan setelah intervensi.Saran Untuk peneliti selanjutnya untuk meneliti lebih spesifik efek pemberian susu tinggi protein terhadap hormon IGF yang berperan dalam pertumbuhan. Untuk penelitian selanjutnya diharapkan memilih sampel dengan hipoalbuminea agar dapat dilihat dengan jelas perubahan ke kadar albumin normal. Untuk masyarakat lebih memlih susu tinggi protein dalam hal ini protein sempurna karena konsumsi susu tinggi protein dapat menjadi alternatif meningkatkan dan mempertahankan berat badan pada subjek berat badan kurang dan normal serta dapat mempertahankan kadar albumin dalam tubuh tetap normal.

\section{UCAPAN TERIMA KASIH}

Ucapan puji syukur dihaturkan kepada Tuhan Yang Maha Esa karena atas berkatnya sehingga penelitian ini bisa terselesaikan. Juga disampaikan ucapan terima kasih kepada. Bapak Dr Abdul Salam, SKM., M. Kes. dan Sabaria Manti Battung SKM., M.Kes., MSc selaku pembimbing yang telah menuntun peneliti dalam menyusun laporan atau jurnal penelitian ini. Ucapan terima kasih juga disampaikan kepada Ibu Nursyamsiar, selaku kepala Laboratorium Biofarmasi atas perizinannya sehingga dapat melakukan penelitian di Farmasi, dan berkontribusi dalam melancarkan penelitian.

\section{DAFTAR PUSTAKA}

1. Budiarso F, Novi, Ronald O, dan Winston P. 2018. IPTEKS Penyuluhan Tentang Obesitas Dan Pengukuran Indeks Massa Tubuh Pada Masyarakat Kelurahan Malendeng Kecamatan Paal 2 Kota Manado. Jurnal Kedokteran dan Terapik. Volume 6. Nomor 2. Fakultas Kedokteran Universitas Sam Ratulangi Manado.

2. WHO. World Health Organization. 2018. 'Obesity and Overweight'. [cited 2018 Oct 18]. Available fromhttp://www.who.int/mediacentre/factsheets/fs311/en.

3. Ellulu M, Yehia Abed, Asmah Rahmat, Yazan Ranneh, and Faisal Ali. 2014. Epidemiology of Obesity in Developing Countries: Challenges and

4. Almatsier S. 2009. Prinsip-prinsip dasar ilmu gizi. Jakarta: Gramedia Pustaka Utama

5. French W, Sami D, Stephanie A. Shouse, Hexirui Wu, Aubree H, Sun-Ok Lee, Xuan Gu and Jamie I. Baum. 2017. A High-Protein Diet Reduces Weight

6. Kurnia P. 2010. Efek Fortifikasi Fe dan Zn pada biskuit yang diolah dari kombinasi tempe dan bekatul untuk meningkatkan kadar albumin anak balita kurang gizi dan anemia. J Ekplanasi 5(2).

7. Hidayat M, Soeng, S., Wahyudianingsih, R., Ladi JE., Krisetya, YA., dan Elviora, V., 2015. Ekstrak Kedelai Detam 1, Daun Jati Belanda Serta Kombinasinya Terhadap Berat Badan dan Histopatologis Hepar Tikus Wistar. JKKI, 6(4), p. 167-178. 
8. Farnsworth, E.; Luscombe, N.D.; Noakes, M.; Wittert, G.; Argyiou, E.; Clifton, P.M. Effect of a high-protein, energy-restricted diet on body composition, glycemic control, and lipid concentrations in overweight and obese hyperinsulinemic men and women. Am. J. Clin. Nutr. 2003, 78, 31-39. [PubMed]

9. Mitchell, CJ, McGregor, RA, Souza, RFD, Thorstensen, EB. Markworth, JF, Fanning, AC, Poppitt, SD, Cameron-Smith, D. Consumption of Milk Protein or Whey Protein Results in a Similar Increase in Muscle Protein Synthesis in Middle Aged Men. Nutrients. 2015;7(10):8685-8699.

10. Winarsi. 2010. Protein Kedelai \& Kecambah Manfaat Bagi Kesehatan. Penerbit Kanisius: Yogyakarta.

11. Stump SE. Nutrition And Diagnosos-Reklated Care. USA: 17. Liponcott WW Philadhelpia; 2008.

12. Prastowo A, Wiryatum Lestariana, Siti Nurdjhanah, dan Retno Sutomo. 2016. Efek Pemberian Ekstrak Putih Telur Terhadap Peningkatan Kadar Albumin dan IL-6 Pada Pasien Tuberkolosisi Dengan Hipoalbumin. Jurnal kesehatan. Vol 1. No 1, pp 10-18.

13. Mercer T AE, Johnson CA, Yarasheski KE, Carnell NS, Campbell WW. Nutrient Ingestion, Protein Intake, and Sex, but Not Age, Affect the Albumin Synthesis Rate in Humans. American Society for Nutrition. 2007;1734-40.

14. Harna, Clara M.Kusharto, dan Katrin Roosita. 2017. Intervensi Susu Tinggi Protein Terhadap Tingkat Konsumsi Zat Gizi Makro dan Status Gizi Pada Kelompok Usia Dewasa. Jurnal MKMI. Institusi Pertania Bogor. Vol 13. No 4, pp. 355-361.

15. Farzana FD, Ahmed S, Ferdous F, Venderlee L, Khan SH, Roy AK, et al. Biochemical and Dietary Indicators among Vegetarians and Non-Vegetarians: Finding from A Cross Sectional Study in Rural Bangladesh. International Journal of Nutrition and Food Sciences. 2013;2:130-6. 